\title{
TECHNIQUE FOR FRACTIONATION OF BACTERIA IN RUMEN MICROBIAL ECOSYSTEM. II. ATTACHMENT OF BACTERIA ISOLATED FROM BOVINE RUMEN TO CELLULOSE POWDER IN VITRO AND ELUTION OF BACTERIA ATTACHED THEREFROM
}

\author{
HAJIME MINATO AND TSUNEJI SUTO \\ National Institute of Animal Health, Kodaira, Tokyo 187, Japan
}

(Received August 1, 1977)

The attaching ability of a number of bacteria, isolated from bovine rumen, to cellulose powder was examined in vitro. Within the range of organisms examined in this investigation, bacteria possessing the attaching ability to cellulose were strains belonging to Bacteroides succinogenes, Ruminococcus flavefaciens, Ruminococcus albus, Eubacterium cellulosolvens, Eubacterium sp., Megasphaera elsdenii, Veillonella alcalescens, Veillonella parvula, and Fusobacterium sp.

The reaction temperature, among factor which influence the attachment of bacteria to cellulose, had a profound effect. All of bacteria listed above attached to cellulose at $38^{\circ}$. Strains of $B$. succinogenes, $R$. flavefaciens, and $R$. albus did not attach to cellulose at $4^{\circ}$. On the other hand, those of $E$. cellulosolvens, $M$. elsdenii, $V$. alcalescens, and $V$. parvula attached well to cellulose even at the reaction temperature of $4^{\circ}$.

Effect of the presence of various carbohydrates on the attachment of bacteria to cellulose was examined. Methylcellulose almost completely inhibited the attachment of all of bacteria tested to cellulose. The degree of this inhibition by methylcellulose depended on its concentration. Amylopectin partly inhibited the attachment of bacteria to cellulose. Cellobiose specifically inhibited the attachment of $B$. succinogenes strain to cellulose.

An attempt was made to detach or elute bacteria from cellulose by some means. Cells of $B$. succinogenes, $R$. flavefaciens, and $R$. albus, attached once to cellulose at $38^{\circ}$, were detached by cooling treatment at $4^{\circ}$. Cells of bacteria, attached once to cellulose at $38^{\circ}$, except E. cellulosolvens, were eluted with an aqueous solution of methylcellulose. E. cellulosolvens cells, attached to cellulose, were not detached by cooling treatment at $4^{\circ}$ or by elution with a solution of methylcellulose. Ecological implications of the attachment of bacteria to cellulose is also discussed. 
To progress the study on the constitution of microflora in a microbial ecosystem, it will be advisable to develop a new research technique as well as further improvement of the usual culture method, as described in our previous report ( $I$ ). In this respect, a method worthy of trial will be the fractionation of bacteria by utilizing the attaching ability of bacteria to solid substrates.

The attachment of bacteria to a solid matter is a general phenomenon encountered in the natural ecosystem (2), and this is also true of the rumen microbial ecosystem. BAKER and HARRIS (3) found that there exist a great number of morphologically characteristic bacteria attached to solid digesta in the rumen. Minato et al. (4) reported preliminarily that a part of members of rumen bacteria attached to cellulose powder added in vitro. However, they did not examine what kind of bacteria attached to the cellulose powder added.

The number and kind of bacteria caught into test tubes so far by the anaerobic roll tube method are limited (5). Among bacteria isolated from bovine rumen, the bacteria whose attaching ability to cellulose has been noted are Ruminococcus albus (6) and Ruminococcus flavefaciens (7). The attaching ability of other bacteria to cellulose has not been investigated. Therefore, it seemed of significance from the ecological standpoint and from the view of obtaining fundamental informations for the development of a technique for fractionation of bacteria in the rumen, to clarify the kind of bacteria possessing the attaching ability to cellulose.

This report describes the results of our research on the attaching ability of a number of bacteria isolated from bovine rumen to cellulose powder as one of solid substrates, on the effect of several factors on this attachment of bacteria to cellulose, and conditions necessary for the detachment or elution of bacteria from cellulose.

\section{MATERIALS AND METHODS}

Bacteria. Bacteria used in this investigation are listed in Tables $1 \mathrm{~A}$ and $1 \mathrm{~B}$. Bacteria listed in Table 1A are those isolated from the contents of bovine rumen in our laboratory, and identified on the basis of gram stain, morphology, $\mathrm{H}_{2} \mathrm{~S}$ production, utilization of carbohydrates, and end products from carbohydrate fermentation. The detailed characteristics of these bacteria will be described elsewhere. Among the bacteria listed in Table 1B, five strains were purchased from the American Type Culture Collection, and the remaining sixteen strains were supplied through the kindness of Dr. N. O. van Glyswyk, Dr. T. Mitsuoka, Dr. M. P. Bryant, and S. Oshio.

Cellulose powder as an adsorbent for bacterial attachment. Cellulose powder used in this test was Avicel type PH-101 (Asahi Chemical Industry, Ltd., Tokyo), consisting of microcrystalline cellulose of a size of about $40 \mu \mathrm{m}$.

Test on attachment of bacteria to cellulose powder. The anaerobic technique 
Table 1A. Sources of strains examined.

\begin{tabular}{lcc}
\multicolumn{1}{c}{ Name } & No. of strains & Isolated by \\
\hline Bacteroides ruminicola ss. ruminicola & 2 & Authors \\
Bacteroides ruminicola ss. brevis & 26 & $"$ \\
Bacteroides amylophilus & 4 & $"$ \\
Bacteroides sp. & 1 & $"$ \\
Succinimonas amylolytica & 1 & $"$ \\
Butyrivibrio fibrisolvens & 22 & $"$ \\
Borrelia sp. & 1 & $"$ \\
Ruminococcus flavefaciens & 1 & $"$ \\
Ruminococcus albus & 6 & $"$ \\
Megasphaera elsdenii & 1 & $"$ \\
Streptococcus bovis & 1 & $"$ \\
Bifidobacterium sp. & 3 & $"$ \\
Eubacterium ruminantium & 2 & $"$ \\
Eubacterium sp. & 8 & $"$ \\
Propionibacterium acnes & 3 & $"$ \\
Fusobacterium sp. & 1 & " \\
Clostridium sp. & 1 & R. Azuma \\
Selenomonas ruminantium & 2 & E. Miyagawa \\
Succinivibrio sp. & 1 & \\
\hline
\end{tabular}

used throughout this investigation for culturing bacteria was essentially that of Hungate ( 8 ) as modified by Bryant and Burkey (9).

Composition of the RL medium used for culturing the two strains of Veillonella spp. was, per $100 \mathrm{ml}$, mineral solution $1\left(0.6 \% \mathrm{~K}_{2} \mathrm{HPO}_{4}\right), 7.5 \mathrm{ml}$; mineral solution $2\left(0.6 \% \mathrm{KH}_{2} \mathrm{PO}_{4}, 1.2 \%\left(\mathrm{NH}_{4}\right)_{2} \mathrm{SO}_{4}, 1.2 \% \mathrm{NaCl}, 0.12 \% \mathrm{MgSO}_{4} \cdot 7 \mathrm{H}_{2} \mathrm{O}\right.$, $\left.0.12 \% \mathrm{CaCl}_{2} \cdot 2 \mathrm{H}_{2} \mathrm{O}\right), 7.5 \mathrm{ml}$; sodium lactate $(80 \%), 3.2 \mathrm{ml}$; clarified rumen liquor, $30 \mathrm{ml}$; cysteine- $\mathrm{HCl} \cdot \mathrm{H}_{2} \mathrm{O}, 0.05 \mathrm{~g} ; \mathrm{Na}_{2} \mathrm{CO}_{3}, 0.4 \mathrm{~g}$. Composition of the RGMC medium used for culturing other bacteria was, per $100 \mathrm{ml}$, mineral solution 1 , $7.5 \mathrm{ml}$; mineral solution 2, $7.5 \mathrm{ml}$; glucose, $0.15 \mathrm{~g}$; maltose, $0.15 \mathrm{~g}$; cellobiose, $0.15 \mathrm{~g}$; clarified rumen liquor, $30 \mathrm{ml}$; cysteine- $\mathrm{HCl} \cdot \mathrm{H}_{2} \mathrm{O}, 0.025 \mathrm{~g} ; \mathrm{Na}_{2} \mathrm{~S} \cdot 9 \mathrm{H}_{2} \mathrm{O}$, $0.025 \mathrm{~g} ; \mathrm{Na}_{2} \mathrm{CO}_{3}, 0.4 \mathrm{~g}$.

The clarified rumen liquor, contained in both media, was prepared by ultracentrifugation at $95,000 \times g$ for $1 \mathrm{hr}$ at $4^{\circ}$ autoclaved rumen liquor which was identical to CFR-2 of BRYANT and RoBINSON (10). The aqueous solution of sodium resazurin as an indicator of redox-potential was not added to either medium, because it interfered in the measurement of the absorbancy at $600 \mathrm{~nm}$ of each of the cultures of bacteria and uninoculated medium. Three $\mathrm{ml}$ of $\mathrm{RL}$ or RGMC medium was distributed into test tubes $(13 \times 100 \mathrm{~mm})$, with an approximately similar value of transmittance, in $\mathrm{CO}_{2}$ atmosphere free from $\mathrm{O}_{2}$, the test tubes were stoppered with a butyl rubber, and autoclaved at $121^{\circ}$ for $15 \mathrm{~min}$. As shown in Fig. 1, the cells of some bacteria were lysed at the stage of late stationary phase of growth. Therefore, attachment of cells to cellulose was examined by adding cellulose into the culture in an early stationary or late log phase, grown in 
Table 1B. Sources of strains examined.

\begin{tabular}{|c|c|c|}
\hline Name & Strain No. & Supplier \\
\hline $\begin{array}{l}\text { Bacteroides ruminicola ss. } \\
\text { ruminicola }\end{array}$ & ATCC 19189 & $\begin{array}{l}\text { American Type Culture Collec- } \\
\text { tion, Rockville, Md., USA }\end{array}$ \\
\hline Bacteroides ruminicola ss. brevis & ATCC 19188 & $n$ \\
\hline Bacteroides succinogenes & ATCC 19699 & " \\
\hline Lachnospira multiparus & ATCC 19207 & $"$ \\
\hline Megasphaera elsdenii & ATCC 25940 & $"$ \\
\hline \multirow[t]{3}{*}{ Eubacterium cellulosolvens } & 1 & $\begin{array}{l}\text { N. O. van Glyswyk; National } \\
\text { Chemical Research Laboratory, } \\
\text { Pretoria, South Africa }\end{array}$ \\
\hline & 4 & " \\
\hline & 5 & " \\
\hline Bifidobacterium pseudolongum & PNC-2-9-G & $\begin{array}{l}\text { T. Mitsuoka; Institute of Phys- } \\
\text { ical and Chemical Research, } \\
\text { Yamato-shi, Japan }\end{array}$ \\
\hline Bifidobacterium thermophilum & J18-P2-91 & " \\
\hline Veillonella alcalescens & BGM-61 & $" \prime$ \\
\hline Veillonella parvula & BGM-62 & $"$ \\
\hline Ruminococcus albus & 7 & $\begin{array}{l}\text { M. P. Bryant; University of } \\
\text { Illinois, Urbana, Ill., USA }\end{array}$ \\
\hline \multirow[t]{2}{*}{ Bacteroides succinogenes } & $1-2-11$ & $\begin{array}{l}\text { S. Oshio; National Glassland } \\
\text { Research Institute, Nishinasuno, } \\
\text { Japan }\end{array}$ \\
\hline & $4-7-15$ & " \\
\hline \multirow[t]{3}{*}{ Ruminococcus flavefaciens } & $2-1-6$ & " \\
\hline & $4-7-5$ & $"$ \\
\hline & $5-4-3$ & $"$ \\
\hline \multirow[t]{3}{*}{ Ruminococcus albus } & $1-4-16$ & " \\
\hline & $2-4-15$ & $"$ \\
\hline & $4-3-20$ & $"$ \\
\hline
\end{tabular}

$\mathrm{RL}$ or RGMC medium at $38^{\circ}$ for $20-24 \mathrm{hr}$, except in the case of time course experiments. Two tubes were prepared for each strain. These two tubes were prewarmed in a water bath at $38^{\circ}$ for $5 \mathrm{~min}$. To one of them $210 \mathrm{mg}$ of cellulose powder was added in a stream of $\mathrm{CO}_{2}$, and the tube was stoppered with a butyl rubber. Hereafter, the tube to which cellulose was added will be called "a cellulose-added tube," and the other tubewith out the addition of cellulose, "a control tube." These two tubes were shaken gently and then warmed further in a water bath at $38^{\circ}$ for $5 \mathrm{~min}$. Then, these tubes were centrifuged at $377 \times g(1,500 \mathrm{rpm})$ for $1 \mathrm{~min}$ in a centrifuge (Model DC-100 GL, Tomy Seiko Co., Tokyo), equipped with a swing rotor, to sediment the cellulose powder. A tube containing uninoculated medium was added with $210 \mathrm{mg}$ of cellulose powder and treated under the same conditions as above. This treated tube will be called "a control blank tube." The absorbancy (A) of each tube containing a culture was measured in a photometer (Model 1V, Tokyo Photo-electric Co., Tokyo) at $600 \mathrm{~nm}$ by 
using the tube containing uninoculated medium as a blank. The percentage of cells attached to cellulose powder to total cells was calculated from the following equation:

$$
\text { Amount of cells attached to cellulose }(\%)=\left(1-\frac{\mathrm{C}_{\mathrm{cb}}-\mathrm{B}_{\mathrm{c}}}{\mathrm{C}_{\mathrm{cbo}} \times \mathrm{C}_{\mathrm{b}} / \mathrm{C}_{\mathrm{bo}}}\right) \times 100
$$

where $\mathrm{C}_{\mathrm{bo}}$ and $\mathrm{C}_{\mathrm{cbo}}$ indicate $A_{600}$ of the control tube and the cellulose-added tube before treatment, $\mathrm{C}_{\mathrm{b}}$ and $\mathrm{C}_{\mathrm{cb}}$ are $A_{600}$ of the control tube and the cellulose-added tube after the treatment by low-speed centrifugation, and $\mathrm{B}_{\mathrm{c}}$ is the $A_{600}$ of the control blank tube.

Effect of reaction temperature and treatment of cells with Formalin on the attachment of bacteria to cellulose. Strains of bacteria which possessed the ability to attach to cellulose powder at $38^{\circ}$ were examined at $4^{\circ}$. For each strain of bacteria tested, two tubes containing the culture incubated in RL or RGMC medium at $38^{\circ}$ for $20-24 \mathrm{hr}$ were prepared. These two tubes were precooled in a water bath at $4^{\circ}$ for $10 \mathrm{~min}$. Then, to one of the tubes $210 \mathrm{mg}$ of cellulose powder was added under a stream of $\mathrm{CO}_{2}$. These tubes were shaken gently and cooled further in a water bath at $4^{\circ}$ for $5 \mathrm{~min}$. Then, these tubes were centrifuged at $377 \times g$ for $1 \mathrm{~min}$, and the amount of cells attached to cellulose was calculated as described above.

For Formalin treatment, cells of bacteria grown in RL or RGMC medium at $38^{\circ}$ for $20-24 \mathrm{hr}$ were washed once with $0.85 \%$ saline and suspended in the original volume of $0.85 \%$ saline containing $2 \%$ Formalin (Wako Pure Chemical Industries, Tokyo). The cell suspensions were incubated at $38^{\circ}$ for $20 \mathrm{hr}$. The bacterial cells were not washed after this treatment. The amount of cells attached to cellulose was examined by the procedures described above.

Inhibition of the attachment of bacteria to cellulose by various carbohydrates. Two strains of Veillonella spp. and other strains of bacteria tested were cultured at $38^{\circ}$ for $20-24 \mathrm{hr}$ in RL and RGMC medium, respectively. Bacterial cells were harvested by centrifugation, washed twice in $0.85 \%$ saline, and suspended in $0.85 \%$ saline to give a final concentration having an absorbancy of 1.0 at $600 \mathrm{~nm}$ in a spectrophotometer (Model UV-200, Shimadzu Seisakusho, Ltd. Kyoto).

The carbohydrates used in this examination were glucose, maltose, cellobiose, dextrin, methylcellulose $400 \mathrm{cps}$, sodium carboxymethylcellulose (Wako Pure Chemical Industries, Ltd., Tokyo), amylose (Nagase Co., Osaka), amylopectin (Tokyo Kasei Kogyo Co., Tokyo), soluble starch (Kokusan Chemical Works, Ltd., Tokyo), Dextran T 500 (Pharmacia Fine Chemicals, Uppsala). Each of these carbohydrates was dissolved in $0.85 \%$ saline and prepared at two times the concentration desired in the reaction mixture. The solutions of these carbohydrates were autoclaved at $121^{\circ}$ for $10 \mathrm{~min}$ and preserved.

The test tube $(13 \times 100 \mathrm{~mm})$ containing $1.5 \mathrm{ml}$ of the solution of carbohydrate and $1.5 \mathrm{ml}$ of the washed cell suspension, prepared as described above, was used for the measurement of the amount of cells attached to cellulose in the presence 
of a carbohydrate ("inhibition tube"). The test tube containing $1.5 \mathrm{ml}$ of $0.85 \%$ saline and $1.5 \mathrm{ml}$ of the washed cell suspension was used for the measurement of the amount of cells attached to cellulose in the absence of a carbohydrate ("control tube"). For each strain of bacteria tested, two inhibition tubes and two control tubes were prepared. These tubes were prewarmed in a water bath at $38^{\circ}$ for $10 \mathrm{~min}$. To each of the control and inhibition tubes, $210 \mathrm{mg}$ of cellulose powder was added. All the tubes were shaken gently by hand and warmed further in a water bath at $38^{\circ}$ for $5 \mathrm{~min}$. Then, these tubes were centrifuged at $377 \times g$ for $1 \mathrm{~min}$ in a centrifuge equipped with a swing rotor. About $1 \mathrm{ml}$ of the resulting supernatant in each tube was pipetted out and absorbancy of each supernatant was measured at $600 \mathrm{~nm}$ by using a microcell of $1 \mathrm{~cm}$ light-path.

The degree of inhibition of the attachment of the cells to cellulose by carbohydrate was calculated from the following equation:

$$
\text { Inhibition }(\%)=\left[1-\left(1-\frac{C_{s b c}-B_{s c}}{C_{s b}-B_{s}}\right) \div\left(1-\frac{C_{b c}-B_{c}}{C_{b}}\right)\right] \times 100
$$

where $\mathrm{C}_{\mathrm{b}}$ and $\mathrm{C}_{\mathrm{sb}}$ indicate $A_{600}$ of supernatants after low-speed centrifugation of control and inhibition tubes, treated without the addition of cellulose, $\mathrm{C}_{\mathrm{bc}}$ and $\mathrm{C}_{\mathrm{sbc}}$ are $A_{600}$ of the supernatants after low-speed centrifugation of control and inhibition tubes treated with the addition of cellulose, $\mathrm{B}_{\text {sc }}$ is $A_{600}$ of the supernatant after low-speed centrifugation of the solution containing $1.5 \mathrm{ml}$ of $0.85 \%$ saline and $1.5 \mathrm{ml}$ of a carbohydrate solution, with the addition of cellulose, $\mathrm{B}_{\mathrm{c}}$ is $A_{600}$ of the supernatant after low-speed centrifugation of $3 \mathrm{ml} \mathrm{of} 0.85 \%$ saline, with the addition of cellulose, and $\mathrm{B}_{\mathrm{s}}$ is $A_{600}$ of the solution containing $1.5 \mathrm{ml}$ of $0.85 \%$ saline and $1.5 \mathrm{ml}$ of a carbohydrate solution.

Detachment or elution of bacteria from cellulose by various treatments. The washed cell suspension and the solutions of carbohydrates used for these examinations were prepared as described above. The principal experimental conditions were the same as those used for the inhibition test of the attachment of bacteria to cellulose by various carbohydrates.

To examine the detachment of cells from cellulose by the cooling treatment at $4^{\circ}$, cellulose powder was added to the tubes containing the washed cell suspension, and the cells were allowed to attach to them at $38^{\circ}$. Each of the tubes containing the cells attached to cellulose and those containing only the cell suspension was cooled to $4^{\circ}$ and shaken vigorously by hand. The detachment of cells from cellulose was determined by measuring the amount of cells released into fluid after the cooling treatment by spectrophotometer.

To examine the elution of cells from cellulose with a solution of Tween 80 or a carbohydrate, each of the tubes containing the cells attached to cellulose and those containing only the cell suspension was added with a solution of Tween 80 or a carbohydrate prewarmed at $38^{\circ}$ and shaken vigorously by hand. The elution of cells from cellulose was determined by measuring spectrophotometrically the amount of cells released into the fluid after the treatment with the solution of 
Tween 80 or a carbohydrate. Percentage of detached or eluted cells to the total of cells attached to cellulose was calculated by the same method as the degree of inhibition of the attachment of cells to cellulose by a carbohydrate.

\section{RESULTS}

Bacteria possessing the attaching ability to cellulose powder

The attaching ability of cells of many strains, listed in Tables $1 \mathrm{~A}$ and $1 \mathrm{~B}$, to cellulose powder was examined in vitro. As shown in Table 2, bacteria possessing this ability included both classified as cellulolytic bacteria and non-cellulolytic bacteria.

Strains which belong to E. cellulosolvens, M. elsdenii, $V$. alcalescens, and $V$.

Table 2. Bacteria possessing the attaching ability to cellulose powder.

\begin{tabular}{|c|c|c|}
\hline Strain & & Amount of attached bacteria $(\%)$ \\
\hline \multirow[t]{3}{*}{ Bacteroides succinogenes } & ATCC 19699 & 58.9 \\
\hline & $1-2-11$ & 51.7 \\
\hline & $4-7-15$ & 35.2 \\
\hline \multirow[t]{4}{*}{ Ruminococcus flavefaciens } & A-17 & 27.0 \\
\hline & $2-1-6$ & 48.8 \\
\hline & $4-7-5$ & 30.8 \\
\hline & $5-4-3$ & 35.1 \\
\hline \multirow[t]{8}{*}{ Ruminococcus albus } & $2-1$ & 21.5 \\
\hline & $2-3$ & 10.4 \\
\hline & $2 \mathrm{~S}-28$ & 30.4 \\
\hline & $2 S-39$ & 26.1 \\
\hline & 7 & 13.2 \\
\hline & $1-4-16$ & 57.3 \\
\hline & $2-4-15$ & 50.2 \\
\hline & $4-3-20$ & 30.1 \\
\hline \multirow[t]{3}{*}{ Eubacterium cellulosolvens } & 1 & 0 \\
\hline & 4 & 0 \\
\hline & 5 & 46.3 \\
\hline \multirow[t]{2}{*}{ Megasphaera elsdenii } & $A-25$ & 75.2 \\
\hline & ATCC 25940 & 0 \\
\hline Veillonella alcalescens & BGM-61 & 64.2 \\
\hline Veillonella parvula & BGM-62 & 31.9 \\
\hline \multirow[t]{6}{*}{ Eubacterium sp. } & $2-2$ & 15.6 \\
\hline & $2-5$ & 26.5 \\
\hline & $\begin{array}{l}2-13 \\
2-16\end{array}$ & $\begin{array}{l}35.4 \\
12.1\end{array}$ \\
\hline & $2-33$ & 35.7 \\
\hline & $2-38$ & 21.7 \\
\hline & $2-39$ & 0 \\
\hline Fusobacterium $\mathrm{sp}$. & $7 \mathrm{~S}-19$ & 15.2 \\
\hline
\end{tabular}

The amount of cells attached to cellulose powder was determined as described in MATERIALS AND METHODS. 
parvula possessed the ability to attach firmly to cellulose. Those belonging to $B$. succinogenes, $R$. flavefaciens, and $R$. albus possessed a distinct ability to attach to cellulose. Those belonging to Eubacterium sp. possessed a weaker ability than those listed above. A strain of Fusobacterium sp. possessed a feeble ability to attach to cellulose (Tables 2 and 4).

Among strains belonging to the same species, there existed both capable and incapable of attaching to cellulose. Two strains among the three strains of $E$. cellulosolvens, one of the two strains of $M$. elsdenii, and one strain among the seven strains of Eubacterium sp. did not attach to cellulose. These strains incapable of attaching to cellulose might have lost their attaching ability during repeated transfers on a maintenance agar medium. For this reason, ability of $M$. elsdenii A-25, R. flavefaciens A-17 and $R$. albus $2 \mathrm{~S}-28$ to attach to cellulose decreased gradually or abruptly during repeated transfers. Therefore, to carry out further examination of the attachment of bacteria to cellulose, the strain which possessed the most powerful ability to attach to cellulose among the strains reisolated from the cultures of these bacteria, was used.

The attaching ability of bacteria to cellulose at various stages of growth

By selecting B. succinogenes ATCC 19699 and M. elsdenii A-25 as the representative of cellulolytic and non-cellulolytic bacteria, respectively, the attaching ability of these bacteria to cellulose was examined at various stages of growth (Fig. 1). The cells of both $M$. elsdenii A-25 and B. succinogenes ATCC 19699 at the stage of late logarithmic growth had higher ability to attach to cellulose than those at the stage of early and middle logarithmic growth. The cells of $B$. succinogenes ATCC 19699 were lysed at the stage of late stationary growth and their attaching ability to cellulose decreased remarkably at this stage. On the other hand, the cells of $M$. elsdenii A-25 grown for $48 \mathrm{hr}$ were lysed only a little and their attaching ability did not decrease drastically.

Influence of various carbon sources for growth on the attaching ability of bacteria to cellulose

The attaching ability of cells grown on several different carbon sources was compared. Since the kind of carbon sources utilizable by bacteria possessing the attaching ability to cellulose was relatively limited, only glucose, maltose, cellobiose, and lactate were used in this examination. The cells of M. elsdenii A-25, a non-cellulolytic bacterium, grown on maltose were somewhat weaker in their attaching ability to cellulose than those grown on glucose or lactate (Table 3). As to other strains tested, the kind of carbon source for their growth had little effect on the attaching ability of cells to cellulose.

Effect of reaction temperature and Formalin treatment of cells on their attaching ability to cellulose

The reaction temperature had a very profound effect on the attachment of 


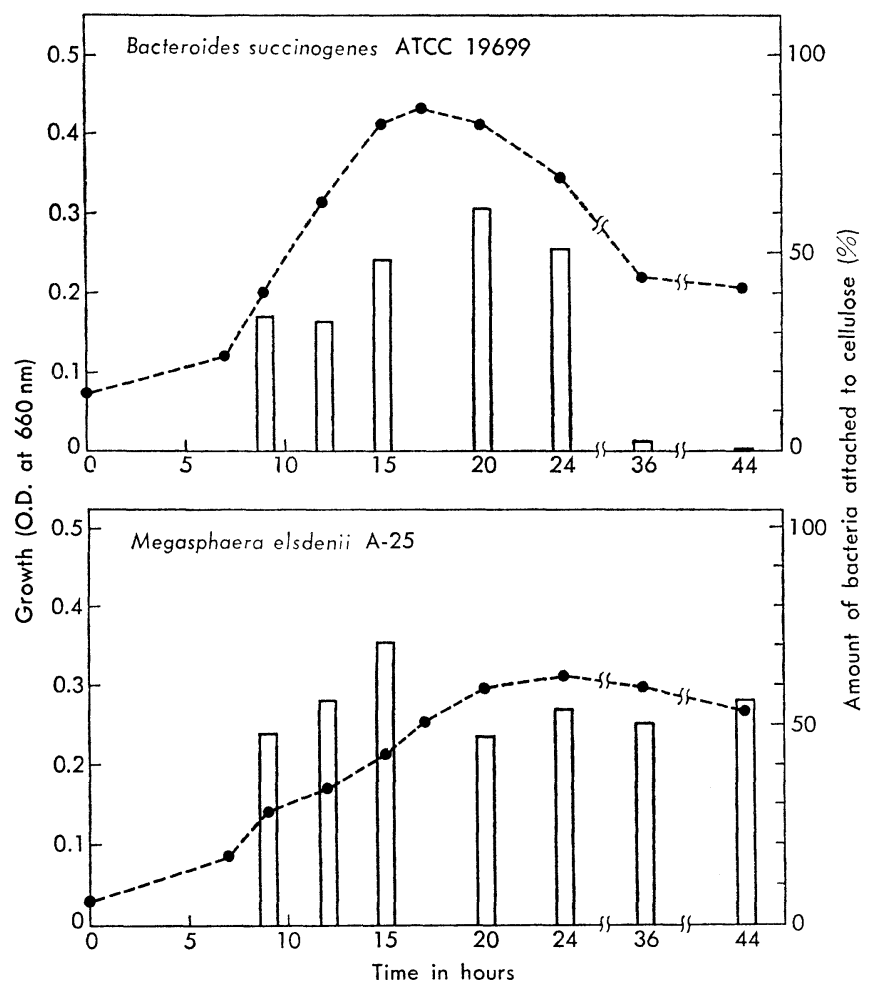

Fig. 1. The attaching ability of cells to cellulose at the various stages of growth.

$80 \mathrm{ml}$ of RGMC medium was inoculated with $5 \mathrm{ml}$ of the culture of bacteria grown in the same medium at $38^{\circ}$ for $20 \mathrm{hr}$, and incubated at $38^{\circ}$. Both growth and the attaching ability of cells to cellulose were determined by using $8 \mathrm{ml}$ samples of the culture, which were removed aseptically under a stream of $\mathrm{CO}_{2}$ at various times of incubation. The amount of cells attached to cellulose was determined as described in MATERIALS AND METHODS. •, growth curve of bacteria; $\square$, amount of bacteria attached to cellulose.

bacteria to cellulose (Table 4). Cells of three strains of B. succinogenes, four strains of $R$. flavefaciens, and four strains of $R$. albus attached well to cellulose at the reaction temperature of $38^{\circ}$ but not at $4^{\circ}$. On the other hand, cells of $E$. cellulosolvens strain 5, a gram-positive cellulolytic bacterium, attached abundantly to cellulose at both reaction temperatures of $38^{\circ}$ and $4^{\circ}$. As to M. elsdenii A-25, $V$. alcalescens BGM-61, and $V$. parvula BGM-62, cells of these strains exhibited a firm attachment to cellulose at both the reaction temperatures of $38^{\circ}$ and $4^{\circ}$.

After the cells of B. succinogenes ATCC 19699 were washed twice with $0.85 \%$ saline, their ability to attach to cellulose decreased remarkably. On the other hand, cells of other bacteria tested retained their attaching ability to cellulose, even after washing treatment with $0.85 \%$ saline.

There was no marked difference in the attaching ability to cellulose between 
Table 3. Comparison of the attaching ability of cells grown on different carbon sources.

\begin{tabular}{|c|c|c|c|}
\hline Strain & $\begin{array}{c}\text { Carbon } \\
\text { source }\end{array}$ & $\begin{array}{l}\text { Growth } \\
\left(\mathrm{OD}_{600}\right)\end{array}$ & $\begin{array}{c}\text { Amount of bacteria } \\
\text { attached }(\%)\end{array}$ \\
\hline \multirow[t]{3}{*}{ Magasphaera elsdenii $\mathrm{A}-25$} & glucose & 0.24 & 46 \\
\hline & maltose & 0.25 & 27 \\
\hline & lactate & 0.26 & 60 \\
\hline \multirow[t]{2}{*}{ Bacteroides succinogenes ATCC 19699} & glucose & 0.31 & 49 \\
\hline & cellobiose & 0.43 & 36 \\
\hline \multirow[t]{2}{*}{ Ruminococcus flavefaciens $\quad \mathrm{A}-17$} & glucose & 0.08 & $\mathrm{NT}^{a}$ \\
\hline & cellobiose & 0.24 & 61 \\
\hline \multirow[t]{2}{*}{ Ruminococcus albus $\quad 2 \mathrm{~S}-28$} & glucose & 0.10 & NT \\
\hline & cellobiose & 0.37 & 47 \\
\hline \multirow[t]{3}{*}{ Eubacterium cellulosolvens 5} & glucose & 0.16 & 56 \\
\hline & maltose & 0.18 & 40 \\
\hline & cellobiose & 0.21 & 42 \\
\hline
\end{tabular}

The cultures of bacteria incubated at $38^{\circ}$ for $20-24 \mathrm{hr}$ in the media, which contained $0.3 \%$ sugar in place of glucose, maltose and cellobiose in the RGMC medium, were used for this examination. The amount of cells attached to cellulose powder was determined as described in MATERIALS AND METHODS.

a $\mathrm{NT}=$ not tested.

Table 4. Effect of reaction temperature and various pretreatments of cells on the attachment of them to cellulose.

\begin{tabular}{|c|c|c|c|c|c|}
\hline \multirow{2}{*}{ Strain } & & \multicolumn{2}{|c|}{ Reaction temperature } & \multirow{2}{*}{$\begin{array}{l}\text { Washed } \\
\text { cells }\end{array}$} & \multirow{2}{*}{$\begin{array}{c}\text { Formalin } \\
\text { treated } \\
\text { cells }\end{array}$} \\
\hline & & $38^{\circ}$ & $4^{\circ}$ & & \\
\hline & & \multicolumn{4}{|c|}{ Amount of attached cells $(\%)$} \\
\hline \multirow[t]{3}{*}{ Bacteroides succinogenes } & ATCC 19699 & 57.8 & 0 & 20.1 & 24.0 \\
\hline & $1-2-11$ & 61.7 & 0 & $\mathrm{NT}^{c}$ & 12.0 \\
\hline & $4-7-15$ & 45.2 & 0 & NT & 2.0 \\
\hline \multirow[t]{4}{*}{ Ruminococcus flavefaciens } & $\mathrm{A}-17$ & 47.2 & 0 & 55.0 & 49.4 \\
\hline & $2-1-6$ & 53.8 & 0 & NT & 64.1 \\
\hline & $4-7-5$ & 40.8 & 0 & NT & 28.5 \\
\hline & $5-4-3$ & 45.1 & 0 & NT & 28.3 \\
\hline \multirow[t]{4}{*}{ Ruminococcus albus } & $2 \mathrm{~S}-28$ & 49.9 & 0 & 37.2 & 50.6 \\
\hline & $1-4-16$ & 67.7 & 0 & NT & 28.0 \\
\hline & $2-4-15$ & 71.7 & 0 & NT & 28.0 \\
\hline & $4-3-20$ & 34.1 & 0 & NT & 32.4 \\
\hline Eubacterium cellulosolvens & 5 & 49.7 & 56.5 & 70.1 & 53.9 \\
\hline Megasphaera elsdenii & $A-25$ & 63.1 & 53.9 & 57.8 & 38.2 \\
\hline Veillonella alcalescens & BGM-61 & 37.5 & 24.8 & 70.4 & 60.2 \\
\hline Veillonella parvula & BGM-62 & 46.4 & 40.6 & 75.4 & 63.7 \\
\hline
\end{tabular}

This examination was carried out according to the procedures described in MATERIALS AND METHODS. The amount of cells attached to cellulose powder was determined as described in MATERIALS AND METHODS.

a $\mathrm{NT}=$ not tested. 
cells treated by washing with $0.85 \%$ saline and those treated with $2 \%$ Formalin.

Inhibition of the attachment of bacteria to cellulose by various carbohydrates

It was assumed that surface nature of bacterial cells would have an effect on the attachment of cells to cellulose. Therefore, an attempt was made to examine whether the attachment of cells of bacteria to cellulose is specifically inhibited by a specific carbohydrate or not.

The attachment of cells of bacteria to cellulose was remarkably inhibited by sodium carboxymethylcellulose (CMC) and methylcellulose (MC), which are derivatives of cellulose and soluble in water (Table 5). The inhibitory effect of $\mathrm{MC}$ on the attachment of cells to cellulose was greater than that of CMC at the same concentration. The degree of inhibitory effect of $\mathrm{MC}$ on the attachment of cells to cellulose increased as the concentrations of $\mathrm{MC}$ in the reaction mixtures became higher.

For other carbohydrates, cellobiose had an inhibitory effect on the attachment of cells of B. succinogenes ATCC 19699 to cellulose. Amylopectin had an inhibitory effect on the attachment of all of bacteria tested to cellulose. However, the degrees of inhibition by amylopectin varied according to bacteria. The inhibitory effect of amylopectin on the attachment of cells to cellulose was observed to be more remarkable in $R$. flavefaciens A-17, $R$. albus $2 \mathrm{~S}-28$, and $M$. elsdenii A-25 than in other bacteria.

The results obtained here suggest that there are specific attaching sites on the cell surface of bacteria and that these sites can be blocked almost completely by MC and partially by amylopectin.

\section{Detachment and elution of bacteria from cellulose powder}

An attempt was made to detach or elute cells from cellulose powder by various treatments. The results obtained are shown in Table 6 . In B. succinogenes ATCC 19699, R. flavefaciens A-17, and $R$. albus 2S-28, the cells once attached to cellulose at $38^{\circ}$ were detached by the cooling treatment at $4^{\circ}$. In other four strains of bacteria tested, the cells once attached to cellulose were not detached by the cooling treatment at $4^{\circ}$.

With E. cellulosolvens 5, M. elsdenii A-25, $V$. alcalescens BGM-61, and $V$. parvula BGM-62, cells once attached to cellulose at $38^{\circ}$ were not eluted with Tween 80 as a surfactant. With B. succinogenes ATCC 19699, 70-80\% of the cells were lysed during the treatment with Tween 80 . With $R$. flavefaciens A-17 and $R$. albus $2 \mathrm{~S}-29$, about $10 \%$ of the cells were lysed by the treatment with over $0.01 \%$ of Tween 80 .

As for five strains of bacteria tested, $R$. flavefaciens A-17, $R$. albus 2S-28, $M$. elsdenii A-25, $V$. alcalescens BGM-61, and $V$. parvula BGM-62, cells once attached to cellulose at $38^{\circ}$ were eluted with a solution of CMC or MC. Since the cells of $B$. succinogenes ATCC 19699 formed some aggregates in both CMC and MC solutions, and about $30 \%$ of the cells were sedimented after a low-speed 
Table 5. Inhibition of the attachment of cells to cellulose powder by various carbohydrates.

\begin{tabular}{|c|c|c|c|c|c|c|c|c|}
\hline \multirow[b]{2}{*}{ Carbohydrate } & \multirow[b]{2}{*}{$\begin{array}{c}\text { Concentration } \\
(\%)\end{array}$} & \multicolumn{7}{|c|}{ Strain } \\
\hline & & 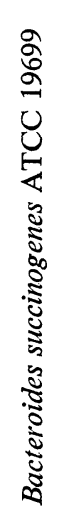 & 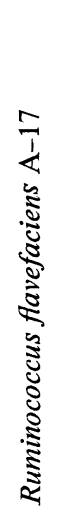 & 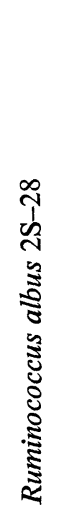 & 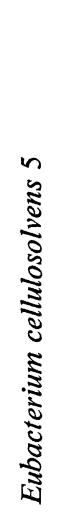 & 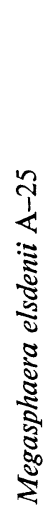 & 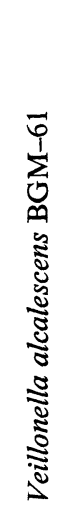 & 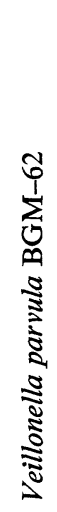 \\
\hline & & \multicolumn{6}{|c|}{ Degree of inhibition $(\%)$} & \\
\hline Glucose & 1 & 8 & 17 & 3 & 13 & 12 & 0 & 0 \\
\hline Maltose & 1 & 22 & 22 & 8 & 12 & 14 & 22 & 3 \\
\hline Cellobiose & 1 & 73 & 24 & 8 & 24 & 15 & 0 & 6 \\
\hline Dextrin & 1 & 0 & 0 & 0 & 24 & 14 & 7 & 11 \\
\hline Amylose & 0.25 & 36 & 19 & 33 & 27 & 34 & 34 & 19 \\
\hline Amylopectin & 0.25 & 43 & 68 & 70 & 27 & 81 & 55 & 61 \\
\hline Soluble starch & 0.25 & 5 & 39 & 30 & 12 & 30 & 8 & 7 \\
\hline Dextran & 0.5 & 19 & 19 & 13 & 9 & 0 & 0 & 0 \\
\hline \multirow[t]{4}{*}{$\mathrm{CMC}$} & 0.1 & 100 & 58 & 82 & 49 & 95 & 37 & 62 \\
\hline & 0.05 & 100 & 58 & 75 & 34 & 92 & 48 & 71 \\
\hline & 0.005 & 7 & 20 & 23 & 15 & 62 & 4 & 8 \\
\hline & 0.0005 & 0 & 16 & 22 & 12 & 25 & 0 & 8 \\
\hline \multirow[t]{4}{*}{ Methylcellulose } & 0.1 & 100 & 100 & 100 & 100 & 94 & 100 & 100 \\
\hline & 0.05 & 93 & 94 & 97 & 85 & 87 & 65 & 74 \\
\hline & 0.005 & 89 & 88 & 87 & 36 & 54 & 30 & 36 \\
\hline & 0.0005 & 54 & 80 & 77 & 24 & 29 & 14 & 19 \\
\hline
\end{tabular}

See MATERIALS AND METHODS for the procedures of this examination. The degree of inhibition of the attachment of cells to cellulose by a carbohydrate was calculated as described in MATERIALS AND METHODS.

centrifugation, accurate amount of detached cells could not be determined. However, flocs formed by cellulose powder and cells of B. succinogenes ATCC 19699 inclined to be deflocculated by the treatment with MC. The cells of $E$. cellulosolvens 5 , attached to cellulose were not eluted by the treatment with MC or CMC. The cells of $R$. flavefaciens A-17, $R$. albus 2S-28, and M. elsdenii A-25, once attached to cellulose, were eluted to some degree by the treatment with amylopectin. These results would not contradict those derived from the above 
Table 6. Detachment or elution of cells attached to cellulose powder by various treatments.

\begin{tabular}{|c|c|c|c|c|c|c|c|c|}
\hline \multirow[b]{2}{*}{ Treatment of floc } & & \multicolumn{7}{|c|}{ Strain } \\
\hline & & 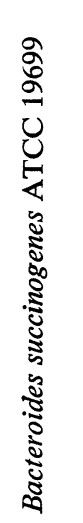 & 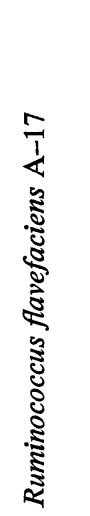 & 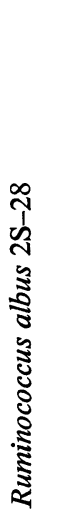 & 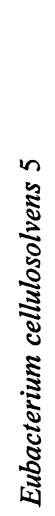 & 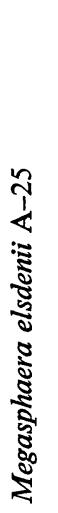 & 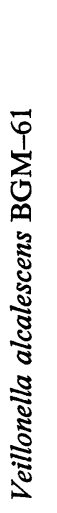 & 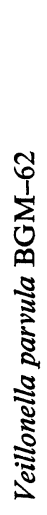 \\
\hline & & & Degr & of $d$ & $\mathrm{chm}$ & $(\%)$ & & \\
\hline \multicolumn{2}{|l|}{ Cooling to $4^{\circ}$} & 69 & 47 & 76 & 0 & 18 & 0 & 0 \\
\hline \multirow[t]{4}{*}{ Tween 80} & $(0.5 \%)$ & $\mathrm{NC}^{a}$ & $\mathrm{NC}$ & $\mathrm{NC}$ & 0 & 15 & 8 & 12 \\
\hline & $(0.1 \%)$ & $\mathrm{NC}$ & $\mathrm{NC}$ & $\mathrm{NC}$ & 0 & 10 & 10 & 11 \\
\hline & $(0.01 \%)$ & $\mathrm{NC}$ & $\mathrm{NC}$ & $\mathrm{NC}$ & 0 & 8 & 11 & 12 \\
\hline & $(0.001 \%)$ & $\mathrm{NC}$ & $\mathrm{NC}$ & $\mathrm{NC}$ & 0 & 3 & 1 & 10 \\
\hline \multirow[t]{2}{*}{$\mathrm{CMC}$} & $(0.1 \%)$ & NC & 93 & 98 & 11 & 94 & 36 & 26 \\
\hline & $(0.05 \%)$ & $\mathrm{NC}$ & $\mathrm{NT}^{b}$ & 88 & 10 & 90 & NT & 30 \\
\hline \multirow[t]{2}{*}{ Methylcellulose } & $(0.1 \%)$ & $\mathrm{NC}$ & 87 & 100 & 0 & 67 & 92 & 71 \\
\hline & $(0.05 \%)$ & $\mathrm{NC}$ & NT & 89 & 0 & 64 & 64 & 75 \\
\hline Amylopectin & $(0.25 \%)$ & 9 & 78 & 93 & 0 & 47 & 27 & 21 \\
\hline
\end{tabular}

See MATERIALS AND METHODS for the procedures of this examination. The degree of detachment or elution of cells attached to cellulose by each treatment was calculated as described in MATERIALS AND METHODS.

${ }^{a} \mathrm{NC}=$ not calculated ${ }^{b} \mathrm{NT}=$ not tested.

examination in the inhibition of the attachment of cells of bacteria by amylopectin.

\section{DISCUSSION}

The strains, which possessed the attaching ability to cellulose among the strains of bacteria tested in the present investigation, were those belonging to $B$. succinogenes, $R$. flavefaciens, $R$. albus, E. cellulosolvens, Eubacterium sp., $M$. elsdenii, $V$. alcalescens, $V$. parvula, and Fusobacterium sp. The strains of bacteria, which exhibited no attaching ability to cellulose, were those belonging to $B$. ruminicola, B. amylophilus, Bacteroides sp., S. amylolytica, B. fibrisolvens, Borrelia sp., S. bovis, E. ruminantium, P. acnes, Clostridium sp., Bifidobacterium sp., $S$. 
ruminantium, and L. multiparus. All of those bacteria possessing the attaching ability to cellulose were incapable of attaching to starch granules, details of which will be described in a subsequent report.

Bacteria possessing the attaching ability to cellulose included both cellulolytic and non-cellulolytic bacteria. However, the species of bacteria capable of attaching to cellulose were limited within the range of the present examination. Therefore, it was assumed that the attaching ability of bacteria to cellulose could be used as one of the items to test for the identification of bacteria. In such a case, it should be pointed out that this ability has to be tested using fresh isolates from the rumen and other microbial ecosystems, because the attaching ability of six strains of $R$. albus, and one strain each of $R$. flavefaciens and $M$. elsdenii to cellulose decreased gradually during repeated transfers on a maintenance medium. However, the attaching ability of several strains reisolated from these old cultures to cellulose revived.

M. elsdenii ATCC 25940 and two strains of E. cellulosolvens did not attach to cellulose. However, we could not solve whether these strains were not able to attach to cellulose at the primary isolation or they lost their attaching ability during repeated transfers on a medium for a long time. These facts show that the property of the attachment of bacteria to cellulose is not a long-lasting property. Therefore, it will be interesting to clarify whether such a property is regulated by episomes as a genetic substance.

It has been generally accepted that liquid digesta have shorter retention time than solid digesta in the rumen. This suggests that the washing-out rate of bacteria attaching to a solid matter is slower than that of those living freely in liquid digesta in the rumen. Therefore, a determinant factor assuring the dominancy of bacteria in the rumen seems to be the attachment of bacteria to a solid matter. Two strains of Veillonella spp. attached well to cellulose in vitro. These bacteria, which are limited in the kind of carbohydrates they are able to utilize as energy source, would have a survival disadvantage in the rumen, compared with those which are able to utilize many kinds of carbohydrates. In spite of this disadvantage, it may partly be due to the attachment of these bacteria to cellulosic matter that members of genus Veillonella are able to constitute a dominant flora in the rumen. B. succinogenes ATCC 19699 also possessed the ability to attach to cellulose in vitro. This finding explains the previous observation that members of B. succinogenes existed on solid matter more abundantly than in liquid digesta in the rumen (11).

It may be presumed that bacteria possessing the attaching ability to solid matter have better chance of obtaining both growth factors and energy sources for growth than bacteria incapable of attaching to a solid. According to our findings, both $M$. elsdenii and $B$. succinogenes can be included in the member of bacteria possessing the attaching ability to cellulose. Members of $M$. elsdenii are capable of producing a relatively large amount of $n$-valerate and $n$-caproate as end products 
of carbohydrate fermentation. On the other hand, members of $B$. succinogenes have been found to require these acids as essential factors for growth (12), and it is likely that members of $B$. succinogenes compete with other bacteria to obtain these acids necessary for their growth in the rumen. If members of both $B$. succinogenes and $M$. elsdenii live in close vicinity on a solid matter rich in cellulose, those of $B$. succinogenes will be able to utilize more efficiently $n$-valerate and $n$-caproate produced from carbohydrate by $M$. elsdenii. The concentration of soluble sugars in the contents of rumen is very low under ordinary circumstances. The members of bacteria attaching to a solid matter will be able to utilize efficiently the soluble sugar products released from cellulosic material by the cellulase action of cellulolytic bacteria and also from starchy matter by the amylase action by amylolytic bacteria. On these considerations, it may be mentioned that among bacteria there exists an admirable symbiosis through giving and receiving of nutritional substances.

For the purpose of obtaining fundamental informations to develop a technique for fractionation of bacteria in the rumen microbial ecosystem by utilizing the attaching ability of bacteria to cellulose powder, influence of several factors on the attachment of bacteria isolated from the rumen to cellulose was examined. One of the interesting phenomena was the effect of the reaction temperature on the attachment of bacteria to cellulose. This was similar to the fact that the reaction temperature had a profound effect on the attachment of rumen bacteria to starch granules as one of the adsorbents (1). Therefore, it may be a general phenomenon that the attachment of bacteria to solid substrates is remarkably affected by the reaction temperature of milieu. The results obtained in the present investigation showed that there were three types of bacteria in their ability to attach to cellulose. The first type of bacteria were those capable of attaching to cellulose at the reaction temperature of both $4^{\circ}$ and $38^{\circ}$. Those capable of attaching to cellulose at $38^{\circ}$ but incapable of attaching at $4^{\circ}$ were the second type. The third type was those incapable of attaching at either $4^{\circ}$ or $38^{\circ}$. These results suggest the possibility that bacteria in the contents of rumen may be fractionated into three groups by treating those twice with cellulose powder at the different reaction temperatures, first at $4^{\circ}$ and subsequently at $38^{\circ}$.

If bacteria once attached to cellulose powder can be detached or eluted by some means, it will become a promising technique for collecting a given group of bacteria in the rumen and other microbial ecosystems. The results obtained in the present investigation showed that bacteria capable of attaching to cellulose can further be fractionated into the following three types of bacteria on the basis of conditions necessary for their detachment and elution: Bacteria of the first type were those that could be detached by the cooling treatment at $4^{\circ}$; those that could not be detached by the cooling treatment at $4^{\circ}$, but be eluted with a solution of methylcellulose, were the second type; and those of the third type were those that could not be detached by the cooling treatment at $4^{\circ}$ and also not be eluted with 
a solution of methylcellulose (Table 6 ). These results were obtained by using only bacteria isolated from the contents of rumen. Nevertheless, these results suggest the possibility that bacteria capable of attaching to cellulose in the rumen include the three types of bacteria mentioned above. In the previous investigation (l), examination was not made on whether bacteria attached to starch granules in the contents of rumen included those which can be detached by the cooling treatment at $4^{\circ}$. However, we observed preliminarily that some strains of bacteria once attached to starch granules can be detached by the cooling treatment at $4^{\circ}$. Details of these results will be described in a subsequent report.

An attempt was made to elute bacteria once attached to cellulose with Tween 80 as one of surfactants. In the present examination, $70-80 \%$ of the cells of $B$. succinogenes ATCC 19699 were lysed by the treatment with over $0.001 \%$ of Tween 80 , and about $10 \%$ of the cells of $R$. flavefaciens A-17 and those of $R$. albus $2 \mathrm{~S}-28$ were lysed by the treatment with over $0.01 \%$ of Tween 80 . Accordingly, it will be undesirable to use Tween 80 as a reagent for the elution of bacteria attached to cellulose. When viable counts in samples from a microbial ecosystem are enumerated, some kind of surfactants are added to the dilution solution in order to prepare a homogeneous cell suspension (13). However, it was found that Tween 80 would destroy cells of some kind of rumen bacteria (Table 6). Therefore, it would be better to avoid its addition to the dilution solution to dilute a sample from the contents of rumen. To expect the detachment of bacteria attaching to a solid matter rich in cellulose in samples from the rumen, it seems rather acceptable to use a dilution solution containing methylcellulose. However, the effect and effective concentration of methylcellulose to be added to the dilution solution will require further investigation.

\section{REFERENCES}

1) H. Minato and T. Suto, J. Gen. Appl. Microbiol., 22, 259 (1976).

2) T. D. BRock, Principles of Microbial Ecology, Prentice-Hall, Inc., Englewood Cliffs (1966), p. 71.

3) F. BAKer and S. T. Harris, Nutr. Abstr. Rev., 17, 3 (1947-1948).

4) H. Minato, A. Endo, Y. Оотомo, and T. Uemura, J. Gen. Appl. Microbiol., 12, 53 (1966).

5) S. O. MANn and E. R. Ørskov, J. Appl. Bacteriol., 36, 475 (1973).

6) R. I. Patterson, J. W. Costerton, and K. J. Cheng, J. Bacteriol., 122, 278 (1975).

7) R. E. Hungate, The Rumen and its Microbes, Academic Press, New York (1966), p. 206.

8) R. E. Hungate, Bacteriol. Rev., 14, 1 (1950).

9) M. P. Bryant and L. A. Burkey, J. Dairy Sci., 36, 218 (1953).

10) M. P. Bryant and I. M. Robinson, J. Dairy Sci., 46, 1446 (1961).

11) H. Minato, A. Endo, Y. Оотомo, and T. Uemura, J. Gen. Appl. Microbiol., 12, 39 (1966).

12) M. J. Allison, M. P. Bryant, and R. N. Doetsch, Science, 128, 474 (1958).

13) S. C. YIN and J. E. MoYer, Appl. Microbiol., 16, 1790 (1968). 